Андрій Вітченко, доктор педагогічних наук, професор Національний університет оборони України імені Івана Черняховського ORCID ID 0000-0002-1694-401X DOI: $10.33099 / 2617-1775 / 2020-01 / 91-102$

\title{
ПІДГОТОВКА МАЙБУТНІХ ДОКТОРІВ ФІЛОСОФІЇ У ВИЩІЙ ВІЙСЬКОВІЙ ШКОЛІ: ДОСВІД, ПРОБЛЕМИ, ШЛЯХИ ВДОСКОНАЛЕННЯ
}

Проаналізовано нормативно-правову основу підготовки фахівиів за третім освітньонауковим рівнем вищої освіти, встановлено суттєві суперечності й недоліки у програмному забезпеченні навчання майбутніх докторів філософії, певні розходження в поглядах їх подолання. Узагальнено принциипи $і$ підходи до підготовки докторів філософії в СПВО, спроектовано рейтингову систему відбору на навчання в ад юнктуру ВВНЗ. На конкретних прикладах розкрито логіку набуття інтегральних результатів навчання майбутніх докторів філософії (комунікативна, дослідницька та лідерська компетентності). Запропоновано авторську модель програми освітньої підготовки ад 'юнктів за спеціальністю 011 «Освітні, педагогічні науки».

Ключові слова: ад'юнктура; вищза військова школа; компетентність; компетентнісний підхід; майбутній доктор філософії; освітньо-наукова програма; рейтингова система відбору на навчання.

Постановка проблеми. У контексті переходу на нову освітню модель, що відзначається компетентнісним спрямуванням і спільною відповідальністю стейкхолдерів за якість вищої освіти, особливої актуальності набувають питання наступності в підготовці докторів філософії, проектування інтегральних показників опанування освітньо-наукових програм за відповідним циклом. Оскільки саме майбутні викладачі й науковці-дослідники визначатимуть успіх подальших освітніх перетворень у системі вищої військової освіти, необхідно простежити загальноєвропейські тенденції впровадження третього ступеня вищої освіти, висвітлити перспективи подальшого вдосконалення сучасної теорії і практики підготовки фахівців найвищої кваліфікації для вищої військової школи України.

Мета статті - проаналізувати сучасні підходи до навчання докторів філософії, розкрити шляхи і способи вдосконалення докторських освітньонаукових програм в умовах освітніх трансформацій.

Методи дослідження. Аналіз нормативно-правових документів, проектів стандартів вищої освіти, наукових джерел 3 метою визначення стану досліджуваної проблеми; узагальнення принципів і підходів до підготовки докторів філософії в СПВО; проектування рейтингової системи відбору на навчання в ад'юнктуру ВВНЗ, інтегральних результатів підготовки ад'юнктів (компетентностей); моделювання програми освітньої підготовки ад’юнкта за спеціальністю 011 «Освітні, педагогічні науки».

Аналіз останніх досліджень і публікацій. Порушеній проблемі присвячено праці Є. Ніколаєва, С. Ніколаєвої, О. Панич, П. Щипанського, 
А. Корецького та ін. Окремі аспекти підготовки майбутніх докторів філософії висвітлюються в розвідках Л. Жураковської, Т. Федотової, Л. Халанчук та ін.

Сучасні дослідники виокремлюють широкий спектр проблемних питань, пов'язаних із підготовкою докторів філософії. Зокрема, С. Ніколаєва актуалізувала проблему проектування докторської освітньо-наукової програми за спеціальністю 011 «Освітні, педагогічні науки». Дослідниця розкрила особливості розроблення освітньо-наукової програми за спеціалізацією «Теорія і методика навчання іноземних мов», визначила зміст, етапи, форми звітності аспірантів за результатами опанування освітнього компонента. Втім окремі положення, сформульовані у статті С. Ніколаєвої, не отримали належного обгрунтування, зокрема кредитне навантаження освітньо-наукової програми в обсязі 46 кредитів ЄКТС, співвідношення нормативних і вибіркових дисциплін (28 і 12 кредитів СКТС відповідно). Потребує уточнення й авторське бачення перспективи подальшого розроблення проблеми у «визначенні та описі компетентностей випускника аспірантури» $[6,46]$, оскільки в разі корегування цільових настанов i результатів навчання необхідно буде переглянути $\mathrm{i}$ змістове, і технологічне забезпечення відповідної програми.

Певні відповіді на вищевикладені дискусійні моменти знаходимо у праці Є. Ніколаєва «Як в Україні створити сучасну систему підготовки докторів філософіï (Ph.D.)?». Зокрема автором слушно наголошується на тому факті, що «підготовка докторів філософії в Україні передбачатиме освітню складову в обсязі 30-60 кредитів ЄКТС (що еквівалентно одному-двом семестрам навчання)» $[5,10]$. Отже, варіант кредитного навантаження докторської освітньо-наукової програми обсягом 46 кредитів СКТС є помилковим.

Окремої уваги заслуговують критичні зауваження $€$. Ніколаєва, пов'язані 3 відсутністю науково обгрунтованих «вимог до конкретного змісту освітньої програми підготовки аспірантів, інституційного забезпечення спроможності ВНЗ та наукових установ реалізувати освітню складову програм підготовки на належному (європейському, світовому) рівні, визначення засад відкриття спільних аспірантур, посилення фінансового забезпечення діяльності аспірантури» $[5,10]$.

Завдяки порівняльному аналізу сучасної практики підготовки докторів філософії вітчизняні дослідники визначили цілу низку тенденцій, врахування яких сприятиме ефективному вирішенню наявних проблем. На думку авторів статті «Організація підготовки докторів філософії у країнах Європейського союзу та Україні: стан, тенденції, перспективи», до провідних тенденцій належать такі: «збереження різноманітності систем організації докторської освіти, забезпечення права вищих навчальних закладів самостійно формувати власні місії та профілі, а отже, і власні пріоритети з погляду програмних i дослідницьких уподобань; стандартизація вищої освіти у частині забезпечення розвитку здобувачів вищої освіти та дослідників їх зайнятості на теренах Європи чи України відповідно; збільшення в структурі докторських програм спеціалізованих навчальних курсів і тренінгів» $[9,141]$.

В окремих розвідках за порушеною проблемою спостерігаються спроби ототожнення та підміни понять (компетентність і компетенція, навчання i 
викладання тощо), спотвореного тлумачення наукових дефініцій, хибного теоретизування. Наприклад, ненауковий характер мають твердження Ю. Козловського про «поєднання методів навчання (викладача), учіння (аспіранта)» $[2,144]$, «можливість трансформації класичних методів навчання та методів пізнання у методи навчання в умовах аспірантури» [2, 145]. Поперше, навчання є спільною діяльністю того, хто вчить (викладача), і того, хто вчиться (аспірант, ад'юнкт), а методи навчання за класифікацією відомого дидакта М. Мархмутова поділяються на методи викладання і методи учіння [4]. По-друге, класифікація методів навчання здійснюється в педагогіці за певними ознаками (за джерелом передавання і характером сприйняття інформації, за ступенями розвитку самостійної пізнавальної діяльності тих, хто навчається тощо), тоді як умови є лише чинниками, що опосередковано впливають на вибір методів навчання.

На підставі проведеного аналізу публікацій з'ясували наявність розходжень у поглядах на проектування цілей, змісту і результатів навчання здобувачів третього рівня вищої освіти. Останне доводить нагальність поглибленого вивчення наявних проблем, пошуку ефективних шляхів i способів їх вирішення.

Виклад основного матеріалу. Ухвалення трициклової системи вищої освіти припадає на Бергенський саміт міністрів освіти (2005р.), де було визначено декілька провідних настанов щодо розроблення докторського рівня:

1. «...Кваліфікації рівня доктора наук повинні бути повністю узгоджені із наднаціональною системою кваліфікацій Загальноєвропейського простору вищої освіти на основі підходу, що базується на результатах».

2. «Ключовою складовою докторантури $є$ поглиблення знань шляхом проведення оригінальних авторських досліджень».

3. «...Звичайне робоче навантаження за третім циклом навчання у більшості країн складає 3-4 роки роботи. Ми закликаємо університети забезпечити в рамках відповідних докторських програм міждисциплінарне навчання та розвиток замінюваних вмінь та навичок, які б максимально відповідали потребам ринку праці».

4. «Необхідно уникати надмірної формалізації докторських програм» [3].

У подальшому сформульовані настанови доповнювалися й розширювалися за рахунок таких положень: «...число людей із дослідницькими компетентностями має зростати. Докторські програми мусять створювати умови для високоякісних досліджень у межах конкретних дисциплін...» (Льовенське комюніке, 2009); «...вища освіта повинна забезпечити міцніший зв'язок між дослідженнями, викладанням і навчанням на всіх рівнях. <..> У цьому відношенні ми будемо підтримувати різноманітність докторських програм...» (Бухарестське комюніке, 2012); «забезпечення справедливого доступу до вищої освіти», «сприяти соціальній мобільності та постійному професійному розвитку, водночас даючи тим, хто навчається, можливість отримати доступ до вищої освіти та завершити ії на будь-якому етапі свого життя» (Паризьке комюніке, 2018). 3 процитованого випливає низка принципів $i$ nidходів, на яких грунтується підготовка докторів філософії в межах ЄПВО: 
1. Узгодженість кваліфікацій за докторським рівнем.

2. Компетентнісний, міждисциплінарний, розвивальний підходи до розроблення освітньо-наукових програм.

3. Пріоритетність інноваційних дослідницьких завдань, підпорядкованість освітньої компоненти науковій.

4. Відповідність докторських програм актуальним запитам і потребам.

5. Гнучкість, варіативність докторських програм.

6. Інтегральність підготовки доктора філософії як дослідника і викладача.

Окремої уваги заслуговує загальноєвропейська тенденція щодо розширення доступу до здобуття вищої освіти. Втім не слід забувати про наявність об'єктивних і суб'єктивних чинників, що позначаються на рівні підготовки вступників до аспірантури (ад’юнктури). Зокрема шлях офіцера в науку теж може бути тривалим, оскільки далеко не всі випускники-магістри ВВН3 одразу після випуску мають можливість вступати в ад’юнктуру.

Особливої гостроти набуває проблема якості підготовки вступників, які за роки служби втратили певні теоретичні знання, дослідницькі вміння, але при цьому набули бойовий і професійний досвід, який не завжди корелює з теорією, а тому потребує належного наукового осмислення. Як цього досягти на відбірковому етапі? Ось тут і необхідно продумати особливий порядок вступу військовослужбовців в ад'юнктуру, який мотивуватиме їх займатися самоосвітою, постійно підвищувати рівень загальнонавчальної, професійної підготовки. До того ж, такий пропедевтичний відбір сприятиме відсіву раптових здобувачів.

Доцільно впровадити гнучку рейтингову систему відбору на навчання в ад'юнктуру ВВНЗ, що грунтуватиметься на відсотковій шкалі оцінювання й охоплюватиме такі види діяльності вступників:

1. Успішне опанування 2-3 дистанційних курсів, пов'язаних з розвитком загальних компетентностей - іншомовної комунікативної, дослідницької, лідерської. Кожен курс повинен становити 5 кредитів та оцінюватися за нормою 1 кредит - 1 заліковий бал. Максимальна кількість залікових балів - 15 .

2. Участь у наукових заходах університету, до якого вступає здобувач. Кожне повідомлення, виступ або доповідь оцінюється відповідно 1, 2 і 3 балами. Максимальна кількість залікових балів - 15 .

3. Публікація матеріалів наукових досліджень за темою майбутньої дисертації. У нефахових періодичних виданнях: тези - 1 бал, стаття - 3 бали. У фахових періодичних виданнях: тези -2 бали, стаття -5 балів. У науково метричних виданнях - 15 б. за кожну публікацію. Максимальна кількість залікових балів -50 .

4. Написання аналітичного огляду зарубіжних і вітчизняних публікацій за темою майбутнього дослідження, наукового реферату та його захист - по 10 балів. Максимальна кількість залікових балів - 20 .

Протягом останніх років було напрацьовано нормативне забезпечення підготовки докторів філософії, завдяки якому, на жаль, не вдалося повною мірою подолати наявні недоліки: 
1. Поверховість і суперечливість нормативних вимог до інтегральних результатів навчання за третім рівнем вищої освіти (табл. 1).

2. Брак наукового обгрунтування докторських освітньо-наукових програм, дисбаланс між їх компонентами, надмірне перевантаження аспірантів (ад’юнктів).

3. Компілятивний підхід до проектування цілей, змісту і результатів навчання.

4. Формальний характер внутрішніх механізмів забезпечення якості освітньо-наукових програм, зокрема щодо контролю самостійної роботи аспірантів (ад’юнктів).

5. Експериментаторство, примітивізація i бюрократизація процедури захисту дисертацій.

Таблиця 1

Порівняльна характеристика нормативно визначених компетентностей доктора філософії

\begin{tabular}{|c|c|}
\hline Постанова КМУ № 261 & Накази МОНУ № 600 та 1648 \\
\hline & \begin{tabular}{l}
\multicolumn{1}{c}{ Інтегральна: Здатність } \\
комплексні проблеми в галузі професійної та/або \\
дослідницько-інноваційної діяльності, що \\
передбачає глибоке переосмислення наявних та \\
створення нових цілісних знань та/або \\
професійної практики
\end{tabular} \\
\hline $\begin{array}{ccc}\text { Здобуття } & \text { глибинних } & \text { знань } \\
\text { спеціальності (групи спеціальностей) }\end{array}$ & $\begin{array}{l}\text { Знання та розуміння предметної області та } \\
\text { розуміння професійної діяльності. }\end{array}$ \\
\hline $\begin{array}{c}\text { Оволодіння } \\
\text { (філософськими) компетентностями }\end{array}$ & $\begin{array}{l}\text { Здатність до абстрактного мислення, } \\
\text { аналізу та синтезу }\end{array}$ \\
\hline 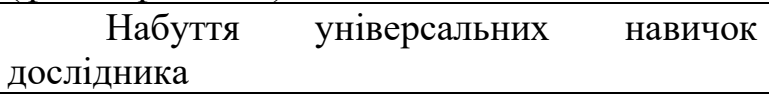 & $\begin{array}{lll}\text { Здатність проведення } & \text { досліджень } & \text { на } \\
\text { відповідному рівні. } & & \\
\end{array}$ \\
\hline $\begin{array}{l}\text { Здобуття мовних компетентностей, } \\
\text { достатніх для представлення та обговорення } \\
\text { результатів своєї наукової роботи іноземною } \\
\text { мовою (англійською або іншою відповідно } \\
\text { до специфіки спеціальності) в усній та } \\
\text { письмовій формі, а також для повного } \\
\text { розуміння іншомовних наукових текстів } 3 \\
\text { відповідної спеціальності }\end{array}$ & $\begin{array}{l}\text { Здатність спілкуватися державною мовою } \\
\text { як усно, так і письмово. } \\
\text { Здатність спілкуватися іноземною мовою. }\end{array}$ \\
\hline
\end{tabular}

Особливе занепокоєння викликає брак наступності у визначенні результатів навчання (компетентностей) між другим і третім рівнями вищої освіти, спотворення сутності компетентнісного підходу, оскільки фактично компетентність як інтегральний результат підготовки фахівців підміняється окремими іiі компонентами (знаннями, вміннями, навичками тощо). При цьому проігноровано ключове положення Закону України «Про вищу освіту» щодо поступового ускладнення компетентностей, їх збагачення залежно від рівня вищої освіти («є результатом навчання на певному рівні вищої освіти» [1]). Наприклад, у проекті стандарту вищої освіти для третього рівня доктора філософії за спеціальністю 253 «Військове управління (за видами збройних сил)» замість компетентностей подано перелік здатностей, що мають імовірнісний характер: «К01. Здатність до набуття універсальних навичок дослідника: пошуку, систематизації і синтезу інформації з різних джерел. К02. 
Здатність формувати системний науковий світогляд, проявляти креативність, продукувати і приймати обгрунтовані рішення» [8]. Окремі формулювання примітивізують навчання, зводять його до набуття фрагментарних якостей, опанування окремих наукових методів і форм відображення навколишньої дійсності, наприклад: «К03. Здатність до абстрактного, критичного мислення, аналізу та синтезу... К06. Здатність до організації та проведення навчальних занять 3 використанням теоретичних та методологічних напрацювань власного наукового дослідження» [8].

У процитованому проекті стандарту без належного пояснення розмежовано компетентності й результати навчання, при цьому останні набули вузькоаспектного, переважно знаннєцентричного спрямування. Окремі формулювання невиправдано розширюють предмет дисертаційного дослідження доктора філософії до рівня доктора наук. Спостерігається неузгодженість, формалізація, надмірне абстрагування результатів навчання (наприклад, «знати ...сучасний стан наукових знань», «здійснювати публічну апробацію результатів досліджень, сприяти їх поширенню в науковій та практичній сферах» [8]). Проте найбільшою проблемою є відсутність логічної послідовності й наступності в набутті визначених результатів, що власне і прирікає цей стандарт на технологічне фіаско. Крім того, всі без винятку стандарти позбавлені засобів діагностики, що унеможливлює якісний контроль результатів навчання ад'юнктів і призведе до формалізації цієї процедури під час акредитації спеціальностей.

Чи є вихід із ситуації, що склалася навколо компетентностей доктора філософії? Безумовно, є. Він передбачає відмову від примітивних розробок у сфері компетентнісного підходу (проект Тьюнінг) і переорієнтацію на наукове обгрунтування системи компетентностей для неперервної освіти. Необхідно відпрацювати таку взаємопов'язану сукупність інтегральних результатів, що піддаватиметься вимірюванню на заключному етапі навчання під час акредитації спеціальності чи державної атестації.

Пропонуємо таке співвідношення груп компетентностей для третього рівня вищої освіти: загальні компетентності - $20 \%$, професійні - $40 \%$, фахові - $40 \%$. Загальна кількість - 10-12.

Логіку набуття майбутнім доктором філософії інтегральних результатів навчання розкриємо на прикладі комунікативної, дослідницької та лідерської компетентностей.

\section{Комунікативна компетентність доктора філософії:}

знання правил ведення наукової дискусії, прийомів аргументації, вираження та відстоювання власної позиції; начитаність, виразність і багатство мовлення, пасивний словниковий запас - не менше 66 тис. слів, активний лексичний запас - 12 тис. слів;

уміння доступно, виразно i переконливо передавати власні думки; цілеспрямовано, творчо будувати колективну інтерактивну комунікацію, успішно налагоджувати міжособистісну комунікативну взаємодію в освітньопрофесійному та науковому середовищі, гнучко будувати власну комунікативну поведінку у проблемній ситуації, підтримувати діалогічну 
комунікацію і первинний науковий дискурс; здійснювати апробацію матеріалів дисертаційного дослідження, оприлюднювати результати наукового пошуку 3 використанням різних видів i форм звітності (повідомлення, виступ, аналітичний огляд);

досвід спостереження та участі в науковій дискусії, аргументованого обміну думками та контраргументами з опонентами;

комунікабельність, інтерактивність, індивідуальність мовлення;

цінності: виважене i коректне ставлення до критичних висловлювань опонента; нормативність, тактовність, лаконізм мовлення.

\section{Дослідницька компетентність доктора філософії:}

знання теорії i методології фундаментальних досліджень; методики організації наукового пошуку, спрямованого на формування нових підходів до розв'язання актуального і вагомого наукового питання (сукупності теоретичних i прикладних завдань - до 4-х); системи загальних і спеціальних методів дослідження; кваліфікаційних вимог до підготовки, експертизи та захисту дисертацій, персональної відповідальності за їх порушення; норм і правил наукової етики;

уміння виявляти наявні суперечності в навколишній дійсності і самостійно визначати підходи до їх подолання, застосовувати основні види наукового аналізу (класифікаційний, аналіз відносин, причинно-наслідковий); ініціювати інноваційні наукові проекти і брати участь у реалізації дослідницьких завдань; добирати й корегувати систему дослідницьких методів, оформлювати i презентувати власні наукові здобутки відповідно до чинних вимог, 3 дотриманням принципу академічної чесності;

досвід планування, організації та проведення самостійного наукового дослідження за ініційованою темою інноваційного спрямування; активної участі в наукових заходах в якості спікера (диспутанта), діалогічної комунікації 3 широкою науковою спільнотою та громадськістю;

інноваційність («почуття нового»), ініціативність, критичність, відповідальність, доброчесність, толерантність, лідерство та автономність; цілеспрямованість у досягненні системного вирішення порушеного наукового питання;

ціннісне ставлення до альтернативних аргументованих наукових поглядів, шляхів і способів розв'язання дослідницьких завдань.

\section{Лідерська компетентність:}

знання основних стратегій лідерства в науковій i науково-технічній діяльності;

уміння формулювати і корегувати спільні цілі, на прогностичній основі керувати науковими проектами, забезпечувати продуманий добір відповідного дослідницького інструментарію та ресурсів;

наполегливість, рішучість у відстоюванні інтересів групи (колективу), об'єктивність, принциповість, вимогливість, відкритість і прозорість у визначенні персонального внеску щодо реалізації дослідницьких завдань; 
досвід успішної реалізації дослідницьких цілей в інтересах групи (колективу), продуктивного попередження (вирішення) конфліктів, порушень академічної доброчесності та захисту авторських прав;

цінності: перспективний особистісний розвиток підлеглих, колективу в цілому; духовне самовдосконалення, професійне і наукове визнання.

Суттєвого корегування потребує сучасна практика проектування навчального змісту освітньо-наукової програми $(\mathrm{OH})$ за третім рівнем вищої освіти, що відзначається низкою недоліків:

1. Брак наступності між ОНП за магістерським і докторським рівнями.

2. Дисбаланс у співвідношенні змістових компонентів - нормативного і варіативного; теоретичного, практичного і дослідницького.

3. Нівелювання інноваційності та гнучкості, формалізм у проектуванні навчального змісту, видів і форм навчально-пізнавальної, самоосвітньої роботи ад’юнктів (аспірантів).

Подоланню визначених недоліків заважає недосконала нормативноправова база. Яскравим прикладом формалізму в підходах до визначення змісту навчання майбутніх докторів філософії $є$ п. 26 Порядку підготовки здобувачів вищої освіти ступеня доктора філософії та доктора наук у закладах вищої освіти (наукових установах), затвердженого постановою КМУ від 23 березня 2016 р. № 261. Саме у цьому пункті міститься норма, за якою «індивідуальний навчальний план аспіранта (ад’юнкта) повинен містити перелік дисциплін за вибором аспіранта (ад'юнкта) в обсязі, що становить не менш як 25 відсотків загальної кількості кредитів ЄКТС. При цьому аспіранти (ад'юнкти) мають право вибирати навчальні дисципліни, що пропонуються для інших рівнів вищоі освіти (курсив наш - А.В.) і які пов'язані 3 тематикою дисертаційного дослідження, за погодженням із своїм науковим керівником та керівником відповідного факультету чи підрозділу» [7]. Таким чином, закладено підгрунтя для нівелювання розвивального, інноваційного спрямування освітньої підготовки аспірантів (ад’юнктів), які замість опанування нового змісту змушені вивчати те, що передбачено на попередніх рівнях - бакалаврському і магістерському. У такому разі виникають сумніви в якості відбору до аспірантури (ад’юнктури), оскільки аспірант (ад’юнкт) змушений звертатися до попередніх рівнів і студіювати дисципліни, змістом яких він повинен володіти до вступу на спеціальність за третім освітньо-науковим рівнем.

Для успішного проектування освітньої компоненти докторських програм необхідно конкретизувати окремі параметральні показники, від яких залежатиме i продумане навчальне навантаження аспірантів (ад'юнктів), і інноваційний потенціал навчання, i його технологічність. Пропонуємо у процесі розроблення ОНП за третім рівнем дотримуватися таких настанов:

1. Загальний обсяг освітньої компоненти - 30 кредитів (1 семестр) або 60 кредитів СКТС (2 семестри), вибір якого залежить від наявності у здобувачів базової освіти, специфіки наукового дослідження, складності ОНП тощо.

2. Співвідношення аудиторної і самостійної роботи $-1 / 3$ до 2/3.

3. Обсяг змісту освітньої компоненти, що забезпечує набуття системи компетентностей: загальних - $20 \%$, професійних $-40 \%$, фахових $-40 \%$. 
4. Нормативний компонент відображається у вигляді дисциплін, а варіативний - у формі спеціальних курсів і спеціальних семінарів.

Орієнтовний розподіл змісту, обсягу і результатів навчання ад'юнктів за спеціальністю 011 «Освітні, педагогічні науки» подано в таблиці 2.

Таблиця 2

Програма освітньої підготовки ад’юнкта за спеціальністю

011 «Освітні, педагогічні науки»

\begin{tabular}{|c|c|c|}
\hline $\begin{array}{l}\text { Компоненти освітньої } \\
\text { підготовки }\end{array}$ & $\begin{array}{l}\text { Ад’юнкт } 3 \text { базовою } \\
\text { педагогічною освітою } \\
\text { (30 кредитів СКТС) }\end{array}$ & $\begin{array}{l}\text { Ад’юнкт без базової педагогічної } \\
\text { освіти } \\
\text { (60 кредитів } Є К Т С)\end{array}$ \\
\hline Нормативна частина & $\begin{array}{l}3 \text { дисципліни обсягом по } 3 \\
\text { кредити (9 кредитів) } \\
\text { Науково-педагогічна практика } \\
(3 \text { кредити) }\end{array}$ & $\begin{array}{l}9 \text { дисциплін обсягом по } 3 \text { кредити (27 } \\
\text { кредитів) } \\
\text { Науково-педагогічна } \\
\text { кредитів) }\end{array}$ \\
\hline Варіативна частина & $\begin{array}{l}1 \text { спецкурс, } 2 \text { спецсемінари } \\
\text { обсягом по } 3 \text { кредити (9 } \\
\text { кредитів) } \\
\text { Навчально-виробнича або } \\
\text { науково-дослідна практика (3 } \\
\text { кредити) } \\
\text { Виконання освітньо-наукового } \\
\text { проекту за темою дослідження } \\
\text { (3 кредити) }\end{array}$ & $\begin{array}{l}2 \text { спецкурси, } 3 \text { спецсемінари обсягом } \\
\text { по } 3 \text { кредити (15 кредитів) } \\
\text { Навчально-виробнича або науково- } \\
\text { дослідна практика (6 кредитів) } \\
\text { Виконання } \\
\begin{array}{l}\text { проекту засвітньо-наукового } \\
\text { кредити) }\end{array}\end{array}$ \\
\hline Підсумковий контроль & $\begin{array}{l}\text { Асистентська практика і звіт (3 } \\
\text { кредити). } \\
\text { Захист проекту }\end{array}$ & $\begin{array}{lllll}\begin{array}{l}\text { Асистентська } \\
\text { кредити) }\end{array} & \text { практика } & \text { i } & \text { звіт } & \text { (3 } \\
\text { Комплексний } & \text { іспит } & \text { за } & \text { фахом } & \text { або } \\
\text { захист проекту } & & & & \end{array}$ \\
\hline
\end{tabular}

Висновки та перспективи подальших досліджень. Підготовка майбутніх докторів філософії у вищій військовій школі здійснюється відповідно до євроінтеграційної стратегії України, з урахуванням визначених у межах СПВО принципів і підходів. Подальше вдосконалення освітнього процесу за докторськими програмами передбачає підвищення якості відбору на навчання в ад'юнктурі ВВНЗ шляхом активізації самопідготовки вступників та їхнього комплексного рейтингування, розроблення системи компетентностей, проектування навчального змісту ОНП за дидактичними принципами послідовності, наступності, розвивальності, гнучкості, перспективності, єдності теорії, практики і досліджень тощо.

Перспективи подальшого розроблення порушеної проблеми вбачаємо у вдосконаленні механізмів оновлення ОНП, відпрацюванні методики внутрішнього і зовнішнього оцінювання ад'юнктів, налагодженні академічної селекції здобувачів ступеня доктора філософії.

\section{ЛIТЕРАТУРА}

1. Закон України «Про вищу освіту» ERL: https://zakon.rada.gov.ua/laws/show/1556-18 (дата звернення: 01.01.2020).

2. Козловський Ю.М. Інтегративний підхід до підготовки майбутніх докторів філософії у галузі наук про освіту. Підготовка докторів філософіï (PhD) в умовах реформування вищої освіти: матеріали Всеукраїнської науково-практичної конференції 
(Запоріжжя, 5-6 жовтня 2017 р.). Запоріжжя : Запорізький національний університет, 2017. C. 143-145.

3. Комюніке Конференції Міністрів країн Європи, відповідальних за сферу вищої освіти «Загальноєвропейський простір вищої освіти - Досягнення цілей», м. Берген, 19-20 травня 2005 p. ERL: https://zakon.rada.gov.ua/laws/show/994_576 (дата звернення: 01.01.2020).

4. Махмутов М.И. Проблемное обучение. Основные вопросы теории. Москва : Педагогика, 1975. 368 с.

5. Ніколаєв С. Як в Україні створити сучасну систему підготовки докторів філософії (Ph.D.)? ERL: https://www.skeptic.in.ua/wp-content/uploads/How-to-create-a-modern-PhDsystem-in-Ukraine.pdf (дата звернення: 31.12.2019).

6. Ніколаєва С.Ю. Підготовка доктора філософії: загальна характеристика освітньонаукової програми зі спеціальності 011 «Освітні, педагогічні науки». Іноземні мови. 2017. № 3 (91). C. 36-46.

7. Постанова КМУ від 23 березня 2016 р. № 261 «Про затвердження Порядку підготовки здобувачів вищої освіти ступеня доктора філософії та доктора наук у закладах вищої освіти (наукових установах)» ERL: https://zakon.rada.gov.ua/laws/show/261-2016-п (дата звернення: 01.01.2020).

8. Проект стандарту вищої освіти для третього рівня доктора філософії за спеціальністю 253 «Військове управління (за видами збройних сил)» ERL: https://mon.gov.ua/ua/osvita/visha-osvita/naukovo-metodichna-rada-ministerstva-osviti-i-naukiukrayini/proekti-standartiv-vishoyi-osviti (дата звернення: 01.01.2020).

9. Щипанський П.В. Корецький А.А., Капосльоз Г.В., Зайцев М.М. Організація підготовки докторів філософії у країнах Європейського союзу та Україні: стан, тенденції, перспективи. Збірник наукових праць Центру воєнно-стратегічних досліджень НУОУ імені Івана Черняховського. 2018. № 2 (63). С. 136-142.

\section{REFERENCES}

1. Zakon Ukrainy «Pro vyshchu osvitu» ERL: https://zakon.rada.gov.ua/laws/show/1556-18 (data zvernennia: 01.01.2020).

2. Kozlovskyi Yu.M. Intehratyvnyi pidkhid do pidhotovky maibutnikh doktoriv filosofii u haluzi nauk pro osvitu. Pidhotovka doktoriv filosofii $(\mathrm{PhD}) \mathrm{v}$ umovakh reformuvannia vyshchoi osvity: materialy Vseukrainskoi naukovo-praktychnoi konferentsii (Zaporizhzhia, 5-6 zhovtnia 2017 r.). Zaporizhzhia : Zaporizkyi natsionalnyi universytet, 2017. S. 143-145.

3. Komiunike Konferentsii Ministriv krain Yevropy, vidpovidalnykh za sferu vyshchoi osvity «Zahalnoievropeiskyi prostir vyshchoi osvity - Dosiahnennia tsilei», m. Berhen, 19-20 travnia 2005 r. ERL: https://zakon.rada.gov.ua/laws/show/994_576 (data zvernennia: 01.01.2020).

4. Makhmutov M. Y. Problemnoe obuchenye. Osnovnye voprosy teoryy. Moskva : Pedahohyka, 1975. $368 \mathrm{~s}$.

5. Nikolaiev Ye. Yak v Ukraini stvoryty suchasnu systemu pidhotovky doktoriv filosofii (Ph.D.)? ERL: https://www.skeptic.in.ua/wp-content/uploads/How-to-create-a-modern-PhDsystem-in-Ukraine.pdf (data zvernennia: 31.12.2019).

6. Nikolaieva S.Iu. Pidhotovka doktora filosofii: zahalna kharakterystyka osvitno-naukovoi prohramy zi spetsialnosti 011 «Osvitni, pedahohichni nauky». Inozemni movy. 2017. № 3 (91). S. 36-46.

7. Postanova KMU vid 23 bereznia 2016 r. № 261 «Pro zatverdzhennia Poriadku pidhotovky zdobuvachiv vyshchoi osvity stupenia doktora filosofii ta doktora nauk u zakladakh vyshchoi osvity (naukovykh ustanovakh)» ERL: https://zakon.rada.gov.ua/laws/show/261-2016-p (data zvernennia: 01.01.2020).

8. Proekt standartu vyshchoi osvity dlia tretoho rivnia doktora filosofii za spetsialnistiu 253 «Viiskove upravlinnia (za vydamy zbroinykh syl)» ERL: https://mon.gov.ua/ua/osvita/vishaosvita/naukovo-metodichna-rada-ministerstva-osviti-i-nauki-ukrayini/proekti-standartiv-vishoyiosviti (data zvernennia: 01.01.2020). 
9. Shchypanskyi P.V. Koretskyi A.A., Kaposloz H.V., Zaitsev M.M. Orhanizatsiia pidhotovky doktoriv filosofii u krainakh Yevropeiskoho soiuzu ta Ukraini: stan, tendentsii, perspektyvy. Zbirnyk naukovykh prats Tsentru voienno-stratehichnykh doslidzhen NUOU imeni Ivana Cherniakhovskoho. 2018. № 2 (63). S. 136-142.

\title{
PEЗЮМЕ
}

Андрей Витченко,

доктор педагогических наук, профессор Национальный университет обороны Украины имени Ивана Черняховского

\section{Подготовка будущих докторов философии в высшей военной школе: опыт, проблемы, пути усовершенствования}

\begin{abstract}
Проанализирована нормативно-правовая основа подготовки спещиалистов на третьем образовательно-научном уровне высшего образования, установлены существенные противоречия и недостатки в программном обеспечении обучения будущих докторов философии, определенны различия во взглядах на их преодоление. Обобщены приниипь и подходы к подготовке докторов философии в Европейском просторе высшего образования, спроектирована рейтинговая система отбора на обучение в адъюнктуру военного вуза. На конкретных примерах раскрыта логика получения интегральных результатов обучения будущих докторов философии (коммуникативная, исследовательская и лидерская компетентности). Предложена авторская модель программы образовательной подготовки адъюнктов по специальности 011 «Образовательные, педагогические науки».
\end{abstract}

Ключевые слова: адъюнктура; высшая военная школа; компетентность; компетентностный подход; будущий доктор философии; образовательно-научная программа; рейтинговая система отбора на обучение.

\section{SUMMARY}

Andrii Vitchenko, doctor of pedagogical sciences, professor National Defence University of Ukraine named after Ivan Chernyahovskyi

\section{Preparation of the future doctors of philosophy in the higher military school: experience, problems, ways of improvement}

Introduction. Implementation of the third degree of higher education, improvement of the modern theory and practice of training for the specialists of the highest qualification in the Ukrainian higher military school.

Purpose is to analyse modern approaches to the training of PhD students, to discover the ways to improve doctoral educational programmes in the conditions of transformations in education.

Methods. Analysis of the legal documents, draft standards of higher education, scientific sources in order to determine the status of the problem under study; generalization of the principles and approaches to the training of PhD students at the EHEA; designing a ranking system of selection for adjunct training in military higher education, integrated results of adjunct training (competencies); modelling of the programme of adjuncts' educational preparation in the specialty 011 «Educational, pedagogical sciences».

Results. The normative-legal basis of the specialists' training in the third educationalscientific level of higher education is analysed, significant contradictions and shortcomings in the programme of the future doctors of philosophy training and the certain differences in the views of 
their overcoming are pointed out. The principles and approaches to the training of PhD students are generalized, the adjunctrating system for selection to the military training is designed. The necessity to adhere to the following leading provisions concerning organizing the training of the future doctors of philosophy within the EHEA has been proved: consistency of qualifications at the doctoral level; competent, interdisciplinary, developmental approaches to the creation of the educational and scientific programmes; priority of innovative research tasks, subordination of the educational component to scientific; correspondence of doctoral programmes to the actual requests and needs; flexibility, variability of doctoral programmes; the integrality of the PhD training as a researcher and lecturer.

Originality. The specific examples of the logic of acquiring the integral training results of the future doctors of philosophy (communicative, research and leadership competences) that ensure the progressive formation of personal and professional qualities: knowledge - ability - experience ways of activity - values. The author model of the programme for the adjuncts educational training in the specialty 011 "Educational, pedagogical sciences" is offered.

Conclusion. The preparation of future PhDs at a higher military school is carried out in accordance with the European integration strategy of Ukraine, taking into account European principles and approaches. Further improvement of the educational process for doctoral programmes involves improving the quality of selection for training in adjuncture by intensifying the self-training of entrants and their complex rating, developing a system of competences, designing the educational content of the educational and scientific programme on didactic principles of consistency, continuity, perspective, unity of theory, practice and research, etc. Mechanisms for updating educational programmes, methods of internal and external evaluation of adjuncts, academic selection of candidates for Doctor of Philosophy degree require further elaboration and improvement.

Key words: adjuncture; higher military school; competence; competence approach; future Ph.D.; educational and scientific programme; rating selection system for training. 